\title{
NOTAS SOBRE O PAPEL DA HERANÇA HISTÓRICA BRASILEIRA NA “EXPANSÁO” DO PODER JUDICIÁRIO NO DOMIINIO DAS POLÍTICAS PÚBLICAS
}

\author{
NOTES ON THE ROLE OF BRAZILIAN HISTORICAL HERITAGE IN THE \\ "EXPANSION" OF THE JUDICIARY IN THE FIELD OF PUBLIC POLICY
}

\author{
Rafael Gonçalves Fernandes ${ }^{\mathrm{I}}$ \\ Liziane Paixão Silva Oliveira ${ }^{\mathrm{II}}$ (iD)
}

${ }^{\mathrm{I}}$ Centro Universitário de Brasília, Brasília, DF, Brasil. Doutorando em Direito. E-mail: rafaelfernandes.dto@ gmail.com

${ }^{\text {II } C e n t r o ~ U n i v e r s i t a ́ r i o ~ d e ~ B r a s i ́ l i a, ~}$ Brasília, DF, Brasil. Doutora em Direito. E-mail: liziane.oliveira@ceub.edu.br

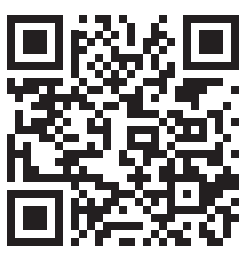

DOI: http://dx.doi.org/10.20912/rdc.v15i37.205

Recebido em: 16.01 .2020

Aceito em: 21.07.2020
Resumo: Pensar o status quo do Brasil e do povo brasileiro, seja pelos seus hábitos e preferências, seja pela sua forma de organização estatal, requer a utilização de um apoio teórico que foi lapidado durante décadas por autores influentes que retrataram os peculiares trejeitos brasileiros. Principalmente pela descrição de características herdadas da troca cultural decorrente da colonização. Dentre tais interpretes do Brasil estão alguns escritores, poetas, músicos e artistas plásticos considerados imprescindíveis na descriçấo dos eventos que formaram as bases dessa sociedade. Explorando esse cenário literário, o presente artigo científico tem como objetivo geral atrelar alguns aspectos históricos específicos da formaçáo do povo brasileiro e do Estado brasileiro à "expansão" institucional do Poder Judiciário, no tocante a formulação e a implementação de políticas públicas. Também serão desmembrados conceitos essenciais ligados ao patrimonialismo e a burocracia. Tais conceitos foram apropriados por alguns autores para explicar a ideia nativa da "cordialidade" brasileira.

Palavras-chave: Interpretes do Brasil. História do Brasil Colônia. Poder Judiciário. Políticas Públicas.

Abstract: Thinking about the status quo of Brazil and the Brazilian people, either by their habits and preferences, or by their form of state organization, requires the use of theoretical support that has been polished for decades by influential authors who portrayed the peculiar Brazilian ways. Mainly by the description of characteristics inherited from the cultural exchange resulting from colonization. Among such interpreters from Brazil are some writers, poets, musicians and artists. Exploring this literary scenario, this scientific article aims to link some specific historical aspects of the formation of the Brazilian people and the Brazilian State to the "expansion" of the Judiciary, especially regarding the formulation and implementation of public policies, dismembering essential concepts related to the 
patrimonialism and bureaucracy. Some classic authors used those concepts to explain the idea of Brazilian "cordiality".

Keywords: Interpreters from Brazil, History of Brazil Colony, Judiciary. Public policy.

\section{Introduçáo}

No Brasil, o passado e o presente andam "lado a lado". Essa constatação realizada por Caio Prado Junior na década de 1940, nos remete às origens históricas do Brasil. $\mathrm{O}$ autor explora a persistência de uma realidade marcada pelas características ruins do passado colonial brasileiro. $\mathrm{O}$ fator principal desse passado que náo se descolava da realidade, estaria na inexistência de uma "ruptura verdadeira" entre os períodos colonial, imperial e republicano. ${ }^{1} \mathrm{~A}$ mera formalidade advinda das divisōes históricas realizadas pelos historiadores e as novas leis aprovadas pelos parlamentares durante esse itinerário histórico, não foram capazes de modificar o status quo de maneira uniforme e para todos.

As "cicatrizes" deixadas em cada época foram carregadas para a atualidade. É nesse sentido que o presente artigo busca como objetivo geral o entrelaçamento dos aspectos históricos da formação do povo brasileiro e do Estado brasileiro à "expansão" do Poder Judiciário, no que tange a formulação e a implementação de políticas públicas. Essa correlação visa entender se tal "expansão" se deve às demandas seculares não concretizadas do povo brasileiro, principalmente aquelas relacionadas aos direitos sociais.

Para investigar tal assertiva, o primeiro tópico tratará da literatura clássica sobre História do Brasil, através da análise dos principais escritos de Gilberto Freyre, Sérgio Buarque de Holanda e Caio Prado Junior, abarcando as influências do Brasil Colônia na caracterização do cenário atual. O segundo tópico aprofundará questóes marcantes no discurso dos interpretes clássicos, principalmente no delineamento do patrimonialismo e da burocracia. O terceiro e último abordará as críticas positivas e negativas da atuação do Judiciário como instância "salvadora da pátria e do povo brasileiro", ${ }^{2}$ demonstrando se há uma ligação entre as origens históricas do Brasil e a organização institucional do Poder Judiciário.

A realização do presente estudo, abordando a problemática exposta e com uma linha de desenvolvimento interdisciplinar, justifica-se na medida que as obras dos ensaístas clássicos são pouco exploradas no cenário jurídico pátrio. $\mathrm{Na}$ visão dos autores deste artigo, caso os aspectos históricos fossem omitidos das linhas escritas abaixo, esta pesquisa não alcançaria a sua finalidade de apontar (com humildade) que há algo "incorreto" na

1 PRADO JR., Caio. Formação do brasil contemporâneo. São Paulo: Companhia das Letras, 2011. Posfácio de Bernardo Ricupero. p. 421.

2 Termo empregado por: SILVA, Jeovan Assis da; FLORÊNCIO, Pedro de Abreu e Lima. Políticas judiciárias no Brasil: O judiciário como autor de políticas públicas. Revista do Serviço Público, Brasília, v. 2, n. 62, p. 119-136, abr./jun. 2011. p. 130. 
atualidade. Principalmente quando o Brasil ocupa a triste colocação de ser um dos países mais desiguais do mundo, apesar de ser a oitava economia global. ${ }^{3}$

\section{Algumas notas sobre os interpretes e as suas leituras do Brasil}

Pensar o status quo do Brasil e do povo brasileiro, seja pelos seus hábitos e preferências, seja pela sua forma de organização estatal, requer a utilização de um apoio teórico que foi lapidado durante décadas por autores influentes que retrataram os peculiares trejeitos brasileiros. Especialmente pela descrição de características herdadas da troca cultural decorrente da colonização. Dentre esses interpretes do Brasil estão diversos escritores, poetas, músicos e artistas plásticos, que deixaram um legado histórico e cultural incomensurável.

Alguns desses interpretes naturalmente ganharam mais visibilidade no cenário social e político do Brasil. Outros foram relegados durante décadas em decorrência do caráter preconceituoso de suas obras. ${ }^{4}$ Contudo, não se pode negar a importância de todos eles na formação de um acervo histórico sobre o Brasil.

Os interpretes escolhidos para fundamentar teoricamente as questóes propostas neste artigo, partiram de uma escolha anterior feita por Antônio Cândido de Mello e Souza no prefácio da obra "Raízes do Brasil", incorporado na edição de 1969.5 Para ele, três obras são consideradas básicas quando o assunto é interpretação do Brasil. A coletânea envolve "Casa Grande e Senzala" de Gilberto Freyre, ${ }^{6}$ "Raízes do Brasil”, de Sérgio Buarque de Holanda, e "Formação do Brasil contemporâneo", de Caio Prado Júnior. $^{8}$

Os três autores elaboraram as suas obras entre as décadas de 1930 e 1940, eram jovens à época da escrita. Foram intelectuais públicos e participaram ativamente da política brasileira em algum momento de suas vidas. ${ }^{9}$ É inegável que as interpretaçóes tiveram influências de diversas frentes, inclusive interferências de algumas ideologias, tal como o socialismo com Caio Prado Junior, bem como de outros autores estrangeiros, como, por exemplo, as construçóes de Max Weber nas obras de Sérgio Buarque de Holanda. ${ }^{10}$ Nessa

3 ONU. Brasil está entre os cinco países mais desiguais. 29 jan. 2018. Disponível em: https://nacoesunidas.org/brasilesta-entre-os-cinco-paises-mais-desiguais-diz-estudo-de-centro-da-onu/. Acesso em: 15 jan. 2020.

4 Podemos citar como exemplo a obra "Populaçóes meridionais do Brasil" de Oliveira Vianna, publicada pela primeira vez em 1918, que contêm uma linguagem considerada racista e xenófoba.

5 HOLANDA, Sérgio Buarque de. Raizes do Brasil, 26. ed. Sáo Paulo: Companhia da Letras, 2008. (Apresentação de Antonio Cândido: O significado de Raízes do Brasil).

6 FREYRE, Gilberto. Casa Grande \& Senzala. Global: São Paulo. 47. ed., 2003; FREYRE, Gilberto. Como e porque escrevo Casa Grande \& Senzala. Casa Grande \& Senzala. ALLCA: São Paulo, 2002. p. 701-721.

7 HOLANDA, Sérgio Buarque de. Raizes do Brasil. São Paulo: Companhia das Letras, 27.ed., 2017.

8 PRADO JR., Caio. Formação do brasil contemporâneo. São Paulo: Companhia das Letras, 2011.

9 RICUPERO, Bernardo. Sete liçóes sobre as interpretaçóes do Brasil. São Paulo: Alameda, 2011. p. 22-23.

10 PRADO JR., Caio. Formação do brasil contemporâneo. São Paulo: Companhia das Letras, 2011. Posfácio de Bernardo Ricupero. p. 429. 
linha, Fernando Henrique Cardoso explica que a principal razão da importação de teorias está na formação acadêmica e/ou vivência no exterior desses autores. ${ }^{11}$

Outros intérpretes também colaboraram para a formação de cenários distintos na formaçáo das dimensões cultural, política e social do Brasil. Podemos citar Mario de Andrade, Euclides da Cunha, Oliveira Vianna, Raymundo Faoro, Victor Nunes Leal, Darcy Ribeiro, Florestan Fernandes, dentre outros. É bom esclarecer que não há uma unidade de pensamento em todo esse acervo, existem, ao revés, diversas contradições e divergências. ${ }^{12}$ Assim, adverte-se que este artigo não se propóe a realizar uma leitura evolutiva (em que uma obra substitui a outra), pois se visa apresentar a contribuição de todas elas para a literatura brasileira, demonstrando possíveis semelhanças entre o cenário descrito pelos autores e as práticas atuais do povo brasileiro e do Estado brasileiro. ${ }^{13}$

Especificamente sobre tais obras, chama a atenção o estilo de escrita e a mudança de paradigma adotada por Freyre em "Casa Grande e Senzala". Além da linguagem peculiar utilizada pelo autor, há uma forte marca interdisciplinar e o abandono de uma perspectiva racial na explicação da formação do brasileiro, que domina os escritos da época. Freyre ressalta a importância do negro na formação do brasileiro de hoje. Para ele, a "Casa Grande" dependia da "Senzala". ${ }^{14}$

Jesse de Souza afirma que em Freyre houve uma "virada culturalista"15 principalmente na construção de uma identidade para o povo brasileiro. Essa perspectiva modificou (ainda que no inconsciente social) a maneira de ver o "mestiço" e a relação social existente entre o senhor e o escravo. Souza faz críticas a essa construção, mas reconhece que Freyre modificou a forma de "pensar" o brasileiro:

11 CARDOSO, Fernando Henrique. Pensadores que inventaram o Brasil. São Paulo: Companhia das Letras, 2012. p. 21-35.

12 Conforme afirmam Botelho e Schwarcz: "Não se trata, é bom deixar claro, de supor a tradição intelectual brasileira como contendo alguma unidade perene em si mesma, tampouco de considerar que todas as interpretaçóes do Brasil que a compóem estejam respondendo a uma mesma questão ou que sejam equivalentes. Também não se imagina que os intérpretes do Brasil dialoguem entre si de maneira, apenas, harmoniosa. O pensamento social é feito de muitas contradiçôes, ajustes e desajustes, e será frutífero entender esse painel, como uma grande e inesgotável multiplicidade. Ainda que afinidades e continuidades entre interpretaçóes contemporâneas ou entre interpretaçóes de diferentes momentos históricos possam ser buscadas, isso não altera a pluralidade constitutiva da tradição intelectual brasileira. Esta, em verdade, se assemelha mais a uma arena de conflitos interpretativos e de disputas sobre, ao fim e ao cabo, o que é o Brasil, como o leitor perceberá ao final da leitura." BOTELHO, André; SCHWARCZ, Lilia Moritz (orgs.) Um enigma chamado Brasil: 29 interpretes e um país. São Paulo: Companhia das Letras, 2009. Apresentação. p. 13.

13 Bernardo Ricupero ressalta que inexiste leitura melhor ou pior quando se fala dos interpretes clássicos, mas há de se falar de contribuiçōes valorosas para a compreensão do país. RICUPERO, Bernardo. Sete liçôes sobre as interpretaçôes do Brasil. São Paulo: Alameda, 2011. p. 22-23.

14 Fernando Henrique Cardoso, afirma que Gilberto Freyre idealizou a constituição dessa relação entre senhor e escravo, pois ele tornava turva a parte ruim da subordinação, da escravidão e do preconceito reinante na época. CARDOSO, Fernando Henrique. Pensadores que inventaram o Brasil. São Paulo: Companhia das Letras, 2012. p. 24.

15 SOUZA, Jesse. A construção do mito da “brasilidade”. In: SOUZA, Jessé (org.). A ralé brasileira: quem é e como vive. Belo Horizonte: UFMG, 2009. p. 36-37. 
Talvez se possa afirmar que Gilberto Freyre, mais do que qualquer outro autor, tenha contribuído para a formulação de uma ideologia que, como tal ajuda a encobrir muito da violência que caracteriza a escravidão e continua a permear as relaçóes raciais no Brasil. Por outro lado, e de maneira complementar, essa ideologia também auxiliou, como não era possível antes, os brasileiros a elaborarem a imagem que gostam de ter de si mesmos. ${ }^{16}$

Por outro lado, para Sergio Buarque de Holanda em "Raízes do Brasil”, a relação entre senhor e escravo - que Freyre considerava uma relação cultural e aparentemente harmônica - revelaria, na verdade, a relação de subordinação entre essas duas classes. Partindo desse contexto, Holanda entende que os aspectos sociais e a herança da escravidão, dificultariam o estabelecimento de uma democracia no Brasil. Tal obra condensa uma narrativa realizada a 84 anos e que perpassa por diversas temáticas organizadas em sete capítulos. O objetivo principal da obra foi demonstrar a ausência de uma coesão nacional. ${ }^{17}$ Holanda criou, ainda, o denominado "homem cordial". Expressão que ganhou espaço e se perpetuou na sociedade e na academia brasileira. Trata-se de uma criação fundamentada nas concepções weberianas de burocracia e de patrimonialismo. Temas que serão aprofundados na próxima seção. ${ }^{18}$

Já Caio Prado Júnior também demonstrou as interferências do período colonial na formação do Brasil contemporâneo. Para ele, existiam três elementos que caracterizaram a Colônia: (a) a produção de bens para exportação, (b) em grandes propriedades rurais, (c) operadas pelo trabalho escravo. $\mathrm{O}$ autor ressalta que a escravidão foi a primeira atividade comercial organizada estabelecida no Brasil. O motivo principal dessa organização era a retirada de riqueza através da exploração do trabalho escravo, fato formador do "sentido da colonização". ${ }^{19}$

Prado Júnior, entendia que a abolição formal da escravidão, foi marcada pela falta de planejamento, tendo em vista que não houve a assistência adequada à população escravizada do Brasil. A partir dessa omissão, diversos problemas sociais foram intensificados, tal como a ausência de emprego, de formaçáo escolar, de moradia adequada e de outros direitos. Para o autor, esse cenário de desequilíbrio social foi responsável pela não superação fática do Brasil Colonial. ${ }^{20}$ Os efeitos da desassistência à população, deixaria marcas difíceis de serem superadas. E foi o que ocorreu. Décadas mais tarde e apesar da construção de uma "Constituição Cidadã", a concretização dos direitos (principalmente dos direitos sociais) ainda não alcança uma parcela significativa dos brasileiros.

16 RICUPERO, Bernardo. Sete liçôes sobre as interpretaçōes do Brasil. São Paulo: Alameda, 2011. p. 99.

17 GODOY, Arnaldo Sampaio de Moraes. Raízes do Brasil, de Sérgio Buarque de Holanda, e o eterno problema do homem cordial. In: Conjur (Embargos Culturais), 5 ju. 2020. Disponível em: https://www.conjur.com.br/2020jul-05/embargos-culturais-raizes-brasil-eterno-problema-homem-cordial. Acesso em 06 ju. 2020.

18 HOLANDA, Sérgio Buarque de. Raizes do Brasil. São Paulo: Companhia das Letras, 27.ed., 2017.

19 PRADO JR., Caio. Formação do brasil contemporâneo. São Paulo: Companhia das Letras, 2011. p. 13-26.

20 PRADO JR., Caio. Formação do brasil contemporâneo. São Paulo: Companhia das Letras, 2011. p. 429-430. 


\section{Uma reflexáo sobre a nossa formaçáo: entre o patrimonialismo, a burocracia e o "rebanho eleitoral"}

Antônio Cândido de Mello e Souza inspirado em Sérgio Buarque de Holanda afirmou: "O brasileiro recebeu o peso das 'relaçóes de simpatia' que dificultam a incorporação natural em outros agrupamentos." 22 Apesar do tom genérico, para o ensaísta Holanda, as relaçóes impessoais, que são características centrais do Estado e das sociedades empresárias, não seriam bem aceitas pelo brasileiro, que tenderia a reduzi-las ao padrão pessoal e afetivo. O sentido da expressão "homem cordial", advém da dualidade que o vocábulo cordialidade pode significar. O sentido original "aquilo que vem do coração", poderia revelar comportamentos bons e ruins. Contudo, o sentido dado por Holanda é da utilização dessas emoçóes de forma inadequada e em ambientes impróprios. ${ }^{23}$ Assim, tal conceito revela um comportamento reprovável e imoral, que não possui conexão semântica com a bondade e alegria do povo brasileiro.

Nessa linha, os interesses particulares que regem o homem em sua vida privada, no seio familiar ou em grupos sociais, também são utilizados pelo povo brasileiro no ambiente social e institucional. Segundo Holanda, o início desta história está na colonização portuguesa, principalmente pela confusão patrimonial da coroa entre bens públicos e bens privados. Conforme afirma Fernando Henrique Cardoso:

A visão que Sérgio Buarque tem é que, se existe um espírito irrequieto entre nós, que permite essas explosões pessoais que quebram a rigidez da sociedade, essa quebra de rigidez não se dá pela transformação da estrutura em benefício de todos, e sim em termos do aplauso para quem consegue quebrar as regras, momentaneamente, graças a um percurso com marca própria, patenteado, e não generalizável. ${ }^{24}$

Essa "quebra" voluntária e reiterada de regras ganhou outras vertentes na literatura contemporânea brasileira. Para Francisco de Oliveira o comportamento reprovável registrado por Holanda parte do "jeitinho" e do "jeitão" do brasileiro. O “jeitão" estaria na herança dos senhores, donos de terras, e do próprio Estado brasileiro, quando ambos ignoravam a existência de milhares de pessoas em situação de pobreza, com o fim da escravidão. O trabalho informal e mal remunerado, foi a única forma encontrada por essas pessoas para garantir a sua subsistência (e da sua família). Assim, se iniciava um ciclo de desleixo e abandono com a população fruto do trabalho escravo. Cenário que também favoreceu o surgimento de uma ocupação urbana desordenada. O “jeitinho”, por outro

21 A expressão "rebanho eleitoral” foi utilizada por Victor Nunes Leal para explicar as limitaçôes do eleitorado brasileiro que careceria de formação e informação para o exercício consciente do voto. LEAL, Victor Nunes. Coronelismo, enxada e voto: o município e o regime representativo no Brasil. 7. ed. edição. São Paulo: Companhia das Letras, 2012. p. 123

22 MELLO e SOUZA, Antônio Cândido. O significado de raízes do Brasil. In: HOLANDA, Sérgio Buarque de. Raízes do Brasil. São Paulo: Companhia das Letras, 27.ed., 2017. P.16-17.

23 HOLANDA, Sérgio Buarque de. Raizes do Brasil. 26. ed. São Paulo: Companhia da Letras, 2008. p. $149-151$.

24 CARDOSO, Fernando Henrique. Livros que inventaram o Brasil. Novos Estudos Cebrap, n. 37, 1993. p. 28. 
lado, seria “(...) a regra não escrita, sem existência legal, mas seguida ao pé da letra nas relaçóes micro e macrossociais". Tal conduta seria compartilhada entre todas as classes sociais, na tentativa de burlar as regras institucionais e "furar a fila." 25

A construção do "homem cordial" tem como influência as obras de Max Weber. ${ }^{26}$ Principalmente na construção teórica das "formas de dominação" em sociedade, em que se encaixam os conceitos de burocracia e de patrimonialismo. Nesse passo, tais conceitos estão em um contexto maior denominado de "dominação". Enquanto essa é o gênero, burocracia e patrimonialismo são espécies de dominação.

Partindo desse recorte teórico, “dominação” refere-se à “(...) probabilidade de encontrar obediência para ordens específicas (ou todas) dentro de um determinado grupo de pessoas." ${ }^{27}$ Essa distinção entre classes de dominação é explicada pelo autor através de um conjunto de açóes que possuem, cada um, a sua "vigência de legitimidade". Trata-se da crença que a sociedade possui na validade dos comandos a serem observados. Assim, nem todas as relaçóes representam uma relação de dominação, pois não possuem a característica da legitimidade (reconhecimento ideal da sociedade em relação ao conteúdo das ordens, o que garante a sua observância - a obediência - pelos membros).

Weber descreve três modalidades puras de dominação legítima, sendo que elas podem ser: a) de caráter racional, que são estabelecidas através de instituiçóes impessoais, ou seja, pelo direito como conformidade e pelo direito como sançáo: dominação legal; b) de caráter tradicional, que consiste na crença pelos indivíduos na força costumeira das regras impostas por determinado ente soberano, respeitadas reiteradamente, mediante uma espécie de submissão do súdito ao soberano: dominação tradicional; e, c) de caráter carismático, que ocorre quando os indivíduos se submetem a dominação de alguém que possui dotes excepcionais ou heroicos, respeitados pela comunidade que a obedece mais pelas emoçóes do que pela racionalidade: dominação carismática. ${ }^{28}$ Neste artigo científico, cabe aprofundar a dominação legal e a tradicional.

A dominação legal perfaz "um exercício contínuo, vinculado a determinadas regras, de funçóes oficiais, dentro de determinada competência (...)." ${ }^{29}$ Nesse contexto, a autoridade institucional consiste no Estado, mas também se expressa em outras instituiçóes, tais como igrejas, comunidade, empresas, escolas, etc. Em todas essas instituições há

25 OLIVEIRA, Francisco de. Jeitinho e jeitão: Uma tentativa de interpretação do caráter brasileiro. Revista Piauí. v. 7, n. 73, p. 32-34, out. 2012. (n.p.).

26 SILVEIRA, Daniel Barile da. Patrimonialismo e burocracia: uma análise sobre o poder judiciário na formaçáo do estado brasileiro. 2006. 301 f. Dissertação (Mestrado em Direito). Universidade de Brasília, Brasília, 2006. p. 73.

27 WEBER, Max. Economia e Sociedade: Fundamentos da sociologia compreensiva. Volume 1. Tradução de Regis Barbosa e Karen Elsabe Barbosa. São Paulo: UnB, 2004. p. 139.

28 Para uma leitura aprofundada sobre as formas de dominação, veja a segunda parte da obra do autor: WEBER, Max. Economia e Sociedade: Fundamentos da sociologia compreensiva. Volume 1. Traduçấo de Regis Barbosa e Karen Elsabe Barbosa. São Paulo: UnB, 2004. p. 140.

29 WEBER, Max. Economia e Sociedade: Fundamentos da sociologia compreensiva. Volume 1. Tradução de Regis Barbosa e Karen Elsabe Barbosa. São Paulo: UnB, 2004. p. 139. 
uma clara divisão hierárquica de atividades, que são representadas por normas e regras técnicas. A racionalidade dessas instituições para Weber está na "separação absoluta" entre o patrimônio pessoal (privado) e o patrimônio da instituição (escritório, no caso patrimônio público para a instituição Estado). A documentação dos processos também é um dos marcos que definem tais instituiçôes.

A burocracia é uma das formas de expressão dessa dominação legal. Trata-se do seu "funcionalismo". Para Weber ela consiste no "tipo mais puro" dessa forma de dominação. Por este motivo, a burocracia é exercida através da divisão de poder e de trabalho baseada em regras impessoais e nos princípios burocráticos. Dentre as características especificas das burocracias modernas, estão: o exercício das atividades burocráticas por pessoas livres e mediante contrato; livre nomeação, tendo como base as regras objetivas preestabelecidas; os servidores respondem as "competências funcionais fixas"; a existência de divisão absoluta e clara do patrimônio pessoal do patrimônio administrativo; e, a existência de um "sistema rigoroso e homogêneo de disciplina e controle de serviço" ${ }^{30}$

Por outro lado, a dominaçáo tradicional está relacionada as crenças que os indivíduos (súditos) tem nas ordens e poderes do senhor. As regras são "tradicionais", ou seja, devem obediência por uma questão meramente de tradição (porque existem normas jurídicas postas). Não existem servidores públicos, mas súditos que respondem as vontades pessoais dos senhores. Nesse cenário, o senhor impere com ou sempre um quadro administrativo, sendo que quando está presente, não carrega as mesmas características do quadro na dominação legal (item aprofundado abaixo - nos parágrafos referentes à burocracia). Nesse sistema, os súditos são recrutados pelo senhor, colonos, etc. Não existe uma racionalidade no agir decisório do senhor, que possui um patrimônio pessoal que se confunde com o patrimônio do quadro administrativo. Nesse passo, Weber afirma que "toda dominaçáo tradicional tende ao patrimonialismo e, com grau extremo de poder senhorial, ao sultanismo." 31

O patrimonialismo é o oposto da burocracia, pois indica o exercício do poder pelo "senhor", através de critérios de foro pessoal. A origem do patrimonialismo está nas raízes da família patriarcal, incorporado pela autoridade senhorial no exercício das atividades sociais e institucionais. O predomínio desse modelo leva ao particularismo e às decisóes baseadas no favoritismo, principalmente nas indicaçóes de cargos públicos. ${ }^{32}$

30 WEBER, Max. Economia e Sociedade: Fundamentos da sociologia compreensiva. Volume 1. Tradução de Regis Barbosa e Karen Elsabe Barbosa. São Paulo: UnB, 2004. p. 144-147.

31 Conforme preleciona Weber: "Denominamos de patrimonial toda dominação que, originalmente orientada pela tradição, se exerce em virtude de pleno direito pessoal, e sultanista toda dominaçáo patrimonial que, com suas formas de administração, se encontra, em primeiro lugar, na esfera do arbítrio livre, desvinculado da tradição. A diferença é inteiramente fluída. Do patriarcalismo originário se distinguem ambas as formas, também o sultanismo, pela existência de um quadro administrativo pessoal.” WEBER, Max. Economia $e$ Sociedade: Fundamentos da sociologia compreensiva. Volume 1. Tradução de Regis Barbosa e Karen Elsabe Barbosa. São Paulo: UnB, 2004. p. 151-152.

32 SILVEIRA, Daniel Barile da. Patrimonialismo e burocracia: uma análise sobre o poder judiciário na formação do 
A transição entre patrimonialismo e burocracia, pode levar a permanência ou confusão entre tais modelos, como, por exemplo, a instituição de uma burocracia que mantém algumas características patrimonialistas.

Foi o que ocorreu no cenário brasileiro. A superação formal do modelo patrimonialista acima conceituado e importado pela colonização portuguesa, levaria a adoção de uma espécie de "estamento burocrático", ${ }^{33}$ que anteriormente era apelidado de "estamento aristocrático" por Raymundo Faoro, em decorrência da não superação fática do modelo patrimonialista pelos condutores da máquina pública. ${ }^{34} \mathrm{~A}$ nomenclatura adotada por Raymundo Faoro traduz a interferência de ordem patrimonial e de interesses particulares no exercício da atividade política burocrática. Segundo o autor, a cultura do "estamento burocrático" dificultou a formação da esfera pública autônoma e eficiente no Brasil. ${ }^{35}$

Também cabe ressaltar que a diferença central entre a constituição do "homem cordial" de Holanda para o "estamento burocrático" de Faoro, está no local que o fenômeno foi observado. Para o primeiro, as relaçôes sociais no Brasil Colônia eram regidas pela informalidade e pelo predomínio do ambiente privado na sociedade. Tratase de uma análise cujo mote está no personalismo. Já o segundo, parte de uma análise institucionalista, descrevendo o agir do brasileiro no interior da máquina pública e da persistência de elementos patrimonialistas na burocracia. A leitura conjugada dessas duas obras, fornece um panorama dos efeitos deletérios da conduta patrimonialistas no seio da administração pública.

Entretanto, Jesse de Souza é um crítico da aplicação do pensamento dos ensaístas clássicos para fundamentar as açôes humanas na atualidade. Para o autor, essa delimitação teórica e histórica do povo brasileiro parte de uma leitura rasa da realidade, que apesar de ter sido sedimentada no ambiente acadêmico, é permeada pelo senso comum:

A cultura do personalismo nos lega o 'homem cordial', ou seja, literalmente o homem que se deixa levar pelo coração, pelos bons ou maus sentimentos e inclinaçóes que acompanham nossa vida afetiva espontânea. Buarque percebe com clareza que o 'homem cordial' é o homem moldado pela família, em contraposição à esfera da política e da economia que exigem disciplina, distanciamento afetivo e racionalidade instrumental, ou seja, tudo aquilo que o homem cordial não é. Por conta disso, o Estado entre nós seria dominado pelo 'patrimonialismo', ou seja, por uma gestão da política baseada no

estado brasileiro. 2006. 301 f. Dissertação (Mestrado em Direito). Universidade de Brasília, Brasília, 2006. p. 57-59.

33 Para Weber o estamento é caracterizado pelos poderes de mando; não liberdade no exercício das atividades presentes no quadro administrativo; subjetividade na escolha que comandarão atividades qualificadas; a apropriação dos bens de administração; e, a não existência de um salário fixo em moeda, pois a lógica consiste em trocas e confusão patrimonial. WEBER, Max. Economia e Sociedade: Fundamentos da sociologia compreensiva. Volume 1. Tradução de Regis Barbosa e Karen Elsabe Barbosa. São Paulo: UnB, 2004. p. 157.

34 FAORO, Raymundo. Os donos do poder: formação do patronato político brasileiro. 3. ed. Rio de Janeiro: Globo, 2001. P. 865.

35 FAORO, Raymundo. Os donos do poder: formação do patronato político brasileiro. 3. ed. Rio de Janeiro: Globo, 2001. P. 86. 
interesse particular por oposição ao interesse público. A partir daí, com a construção do binômio personalismo/patrimonialismo, temos a constituição da interpretação que irá dominar tanto a academia quanto o senso comum do brasileiro até nossos dias. ${ }^{36}$

Além das heranças maléficas na formação do Estado brasileiro, outro fenômeno decorrente da precariedade assistencial à população brasileira, seja na fase colonial, imperial e, até, republicana, prejudicou a formação e consolidação de uma democracia efetiva no país. Trata-se da ausência de preparo intelectual do eleitor brasileiro e, também dos representantes políticos. Essa realidade serviu de combustível para que agentes privados - normalmente com poder econômico - interferissem na vontade do eleitor através do "mandonismo local". Nesse sentido, Victor Nunes Leal afirma que:

A superposiçấo do regime representativo, em base ampla, a essa inadequada estrutura econômica e social, havendo incorporado à cidadania ativa um volumoso contingente de eleitores incapacitados para o consciente desempenho de sua missão política, vinculou os detentores do poder público, em larga medida, aos condutores daquele rebanho eleitoral. Eis aí a debilidade particular do poder constituído, que o levou a compor-se com o remanescente poder privado dos donos de terras no peculiar compromisso do 'coronelismo'. ${ }^{37}$

Cabe advertir que esse histórico de deficiência eleitoral não é uma espécie de "jabuticaba", que se desenvolveu apenas no Brasil. Inclusive, a insatisfação diante da lógica representativa, cujo vetor central está no voto, fez com que alguns países repensassem o modelo tradicional de democracia. A assimetria de informaçóes entre os cidadáos e os representantes políticos, bem como as limitaçôes do próprio eleitorado, levaram à uma releitura da democracia. Nesse sentido, John Keane é um dos principais teóricos que observaram essa mudança. $\mathrm{O}$ autor introduziu o termo "democracia monitória (ou monitorada)". Tal expressão indica o movimento que vem ocorrendo nas últimas três décadas em alguns países, cujo mote está na instituição de novos mecanismos de vigilância, controle e supervisão da democracia. Para Keane:

O termo de som estranho democracia monitória é o mais exato para descrever a grande transformação que está ocorrendo em regiốes como a Europa e em países tão diferentes como os Estados Unidos e a Índia, a Argentina e a Nova Zelândia. A democracia monitória é uma nova forma histórica de democracia, uma variedade de política 'pósparlamentar' definida pelo crescimento rápido de muitos tipos diferentes de mecanismos extraparlamentares de escrutínio de poder. Esses corpos monitórios enraízam-se nas áreas 'internas' do governo e da sociedade civil, bem como em cenários 'entre fronteiras' outrora controlados por impérios, estados e organizações empresariais. (...). O controle central das eleiçóes, dos partidos políticos e dos parlamentos sobre as vidas dos cidadáos está enfraquecendo. A democracia está significando mais do que as eleiçôes, embora

36 SOUZA, Jesse. A construção do mito da "brasilidade". In: SOUZA, Jessé (org.). A ralé brasileira: quem é e como vive. Belo Horizonte: UFMG, 2009. p. 55.

37 LEAL, Victor Nunes. Coronelismo, enxada e voto: o município e o regime representativo no Brasil. 7. ed. ediçáo. São Paulo: Companhia das Letras, 2012. p. 123. 
nada menos. Dentro e fora de estados, monitores independentes de poder começam a ter efeitos tangíveis. ${ }^{38}$

Trata-se de um aperfeiçoamento do sistema democrático contemporâneo, que transforma a democracia em “(...) uma arma acessível e indispensável contra concentraçôes de poder irresponsável e contra os efeitos danosos desse poder." ${ }^{39} \mathrm{Um}$ dos pontos centrais dessa nova concepção está na disseminação da informação sobre como a máquina pública é conduzida. Um desses mecanismos está na ideia de wathdog democracy, que fomenta a criação e proliferação de novos atores independentes ou pertencentes a agências de controle externo, na fiscalização e monitoramento das atividades de interesse público, bem como na intensificação da publicidade das açôes do setor público. ${ }^{40}$

Essa concepçáo contemporânea da democracia surge, também, como uma espécie de tentativa de fornecer uma "sobrevida" ou "renovação" ao sistema democrático. Conforme apontam Steven Levitsky e Daniel Ziblatt na atualidade as democracias tendem a "morrer" de maneira sutil, gradual e através dos instrumentos legalmente constituídos. Trata-se de uma "guerra" que não possui meios sangrentos de execuçáo, mas que carrega objetivos tão enviesados quanto aqueles presentes em guerras civis e golpes de Estado. ${ }^{41}$ Para eles, o equilíbrio do sistema democrático perpassa pela não eleição de candidatos que sejam outsiders e que apregoam uma política anti-establishment. Essa restrição deve ocorrer porque tais agentes tendem a desenvolver um comportamento autoritário quando assumem o poder. Tal conduta autoritária "(i) rejeita regras democráticas; (ii) nega a legitimidade dos seus oponentes; (iii) tolera ou encoraja a violência; e, (iv) é propenso a restringir liberdades civis da mídia e dos seus oponentes.”² Tais indicadores são facilmente observados no agir decisório de alguns agentes políticos, tal como o presidente americano Donald Trump.

Em síntese e conclusão desta seção, tanto as visões dos interpretes clássicos do Brasil, quanto as ponderaçôes interdisciplinares realizadas acima, sobre a abordagem global de assuntos tấo caros ao povo brasileiro, são essenciais para a formaçáo de um pensar o Brasil de forma abrangente e sem preconceitos. As obras dos ensaístas serviram (e continuam servindo) para a compreensão da origem remota e histórica de condutas que até hoje estão "institucionalizadas" no Estado brasileiro, tais como a prática de atos ilícitos por agentes públicos e privados no exercício de funçōes públicas, a interferência

38 KEANE, John. A vida e a morte da democracia. Tradução de Clara Colloto. São Paulo: Ediçóes 70, 2010. p. 619.

39 KEANE, John. A vida e a morte da democracia. Tradução de Clara Colloto. São Paulo: Ediçóes 70, 2010. p. 26.

40 WILLEMAN, Marianna Montebello. Desconfiança institucionalizada, democracia monitorada e instituiçóes superior de controle no Brasil. Revista de Direito Administrativo, Rio de Janeiro, v. 263, p. 221-250, maio/ago. 2013. p. 238.

41 LEVITSKY, Steven; ZIBLATT, Daniel. Como as democracias morrem. Tradução de Renato Aguiar. Rio de Janeiro: Zahar, 2018. p. 19-22.

42 LEVITSKY, Steven; ZIBLATT, Daniel. Como as democracias morrem. Tradução de Renato Aguiar. Rio de Janeiro: Zahar, 2018. p. 33. 
de interesses particulares na condução da máquina pública, bem como a falha na concretização dos direitos fundamentais e sociais elencados na Constituição Federal de 1988, tema que será desenvolvido na seção abaixo com aporte na literatura especializada na temática judiciária.

\section{A expansão institucional do Poder Judiciário e as políticas públicas}

Em decorrência das deficiências de formação do povo e do Estado brasileiro acima trabalhadas, o Poder Judiciário tornou-se um local de soluçáo de conflitos que são da alçada dos Poderes Legislativo e Executivo. Eduardo Appio na obra "O controle judicial de políticas públicas no Brasil”, especialmente no tópico sobre os argumentos contrários a uma intervenção judicial nas políticas públicas, ${ }^{43}$ afirma que há uma divisão de poder expressamente estabelecida na CRFB/88, e quando o Poder Judiciário avança nos assuntos legislativos ou administrativos, acaba atuando indevidamente nas funçóes dos outros dois Poderes. Partindo desta leitura, a conduta do Poder Judiciário é capaz de gerar uma crise de confiança no sistema. ${ }^{44}$

Assim, a substituição da pauta legislativa ou administrativa para o Judiciário, acaba por tornar esvaziadas as funções do legislador ou do administrador, pois haveria, uma "perigosa concentração de funções" no Judiciário. Além disso, surgem problemas orçamentários com a interferência não planejada, o que pode impactar diversos setores da sociedade. O juiz não possui treinamento técnico para compreender questões orçamentárias e a complexidade de uma lei orçamentaria anual a ponto de saber se está alocando o recurso com eficiência. Esse cenário também acaba gerando "superpoderes" ao Poder Judiciário, que cumula as funçôes legislativa, administrativa e judicial. ${ }^{45}$

O juiz não estaria apto a decidir sobre a alocação de recursos nas áreas adequadas. Por exemplo, decidindo de forma individualizada sobre demandas por medicamentos, o magistrado acaba interferindo em uma lógica orçamentária que prejudica outros possíveis beneficiários daquele recurso. Assim, "ao distribuir medicamentos de forma individual os juízes podem estar prejudicando outras políticas públicas na área da saúde.”46 Para Virgílio

43 Nesse passo, Oliveira ressalta que as políticas públicas tradicionalmente são representadas por estágios, por exemplo: inteligência, promoção, prescrição, invocação, aplicação, término e avaliação. $\mathrm{O}$ modelo de ciclos serve para organizar e apresentar as fases das políticas públicas de maneira didática. Contudo, a dinamicidade e a complexidade das políticas públicas não se encaixam perfeitamente nesses estágios, pois demonstram limitaçóes. Não haveria uma divisão linear e nítida entre formulação e implementação de políticas, pois a tomada de decisões é um constante ir e vir, de reformulações, correçôes, que deixa nebulosos os estágios acima descritos. $\mathrm{O}$ processo deve ser visto como um todo interligado. O olhar deve ser global. Nesse sentido, o autor afirma que no início dos estudos, havia uma preocupação maior com o aspecto da formulação, que posteriormente foi alterado para o aspecto da implementação. OLIVEIRA, Luciano Moreira de. O Ministério Público brasileiro e a implementação de políticas públicas. Revista de Informação legislativa, v. 50, n. 198, p. 223-238, abr./jun. 2013. p. 226.

44 APPIO, Eduardo. O Controle Judicial de Politicas Públicas no Brasil. Curitiba: Juruá, 2009. p. 152.

45 APPIO, Eduardo. O Controle Judicial de Políticas Públicas no Brasil. Curitiba: Juruá, 2009. p. 156.

46 SILVA, Virgílio Afonso. O Judiciário e as políticas públicas: entre transformação social e obstáculos à realização 
Afonso Silva "os direitos sociais não podem ser tratados, exceto em casos excepcionais, como se seguissem o mesmo padrão individualista em que se baseiam relaçóes entre um credor e um devedor." ${ }^{47}$

Dessa forma, existe uma vertente da literatura jurídica que é contrária ao posicionamento do Judiciário como formulador de políticas públicas, pois entende-se que a imposição de políticas públicas por esse Poder seria incompatível com as funçóes institucionais e modificaria indevidamente a lógica da representação popular. Haveria a substituição da vontade dos membros do Executivo e Legislativo eleitos, pela vontade de membros não eleitos (juízes). Nesse passo, o Appio afirma que "(...) é a própria Constituição de 1988 que irá definir os limites da liberdade dos governos, não através de cláusulas gerais e abertas à interpretação judicial, as quais poderiam conduzir a um perigoso governo dos juízes, mas por meio de normas constitucionais que impóem limitaçóes concretas aos Poderes da República.”48

Luís Roberto Barroso apesar de discordar do posicionamento elencado acima, resume as três críticas mais utilizadas na literatura jurídica acerca da expansão do Judiciário (e dos seus malefícios) em assuntos como a formulação/implementação de políticas públicas. Segundo o autor, a primeira crítica é a ideológica, sendo que o Poder Judiciário perfaria uma instância conservadora e interromperia a participação popular e política majoritária. Até porque seus membros não sáo eleitos pelo voto direto. A segunda crítica estaria nas capacidades institucionais, em que o Judiciário não revelaria o melhor lugar para a adoção de decisóes complexas, pois existem efeitos imprevisíveis das decisóes. A terceira e última crítica residiria na limitação da participação do debate aos poucos que conseguem acessar o Poder Judiciário, pois há um custo que deve ser arcado para se ter um provimento judicial (exceto nos casos de hipossuficientes econômicos). ${ }^{49}$

Em seguida, Barroso desconstrói todas as críticas realizadas pela literatura jurídica. A primeira desconstrução reside no fato das cortes constitucionais promovem avanços nos direitos fundamentais de minorias, tais como demandas envolvendo negros, mulheres e a populaçáo LGBTQI+. A segunda desconstrução perfaz a ideia de que o Poder Judiciário

dos direitos sociais, Direitos sociais: fundamentos, judicializaçáo e direitos sociais em espécie. Rio de Janeiro: Lúmen Juris, 2010. Coords. Daniel Sarmento; Claudio Pereira de Souza Neto. p. 597.

$47 \mathrm{Na}$ opinião do autor que é fundamentada em outros autores da área, os direitos sociais não podem ser considerados no mesmo nível dos direitos individuais, tendo em vista que "juízes não podem ignorar as políticas já existentes nessas áreas, concedendo de forma irracional e individualista, medicamentos, tratamentos de saúde ou vagas em salas de aula a todo aquele que recorrer ao judiciário". Para o autor os direitos sociais não podem ser negociados no judiciário como uma questáo contratual entre credor e devedor. Ela ultrapassa as barreiras da mera contratualidade. SILVA, Virgílio Afonso. O Judiciário e as políticas públicas: entre transformação social e obstáculos à realização dos direitos sociais. In: SARMENTO, Daniel; SOUZA NETO, Claudio pereira de. (coords) Direitos sociais: fundamentos, judicialização e direitos sociais em espécie. Rio de Janeiro: Lúmen Juris, 2010. p. 597-598.

48 Para aprofundar a temática, veja: APPIO, Eduardo. O Controle Judicial de Políticas Públicas no Brasil. Curitiba: Juruá, 2009. p. 158.

49 BARROSO, Luís Roberto. Contramajoritário, representativo e iluminista: papeis das supremas cortes nas democracias contemporâneas. In: Revista Direito Práx., Rio de Janeiro, Ahead of print, V. 9, N. 4, 2017. 
não ignora o povo. Apesar de seus membros serem guiados por princípios jurídicos e não pela vontade popular, a realização da Constituição, em última análise, reflete a vontade do povo. A última desconstrução está na atribuição do poder ao povo que decide os caminhos que a sociedade deve seguir. Nesse passo, o Judiciário seria uma instância de interlocução entre legislador e a esfera pública. Ademais, o Poder Judiciário não tem pretensóes de substituir os outros dois Poderes. O aspecto contramajoritário das Cortes Constitucionais revelaria, ao final, a consagração da democracia, pois elas defendem os elementos essenciais ao seu funcionamento. ${ }^{50}$

A problemática central dessa exaltação do Judiciário está na nebulosidade entre direito e política. Conforme Barroso, em sua origem, o direito não se separa da política, pois a política representaria a vontade do povo e o direito a razáo e o primado da lei. $\mathrm{Na}$ visão clássica deve haver uma cisão total entre os dois fenômenos, mas em uma visão "real" é necessário um meio termo que náo os cinde totalmente, pois a autonomia do direito em relação a política deve ser relativa. Tal fundamento parte do pressuposto que a complexidade da vida moderna impede uma cisão completa, pois em inúmeros casos há matérias que são difíceis e, quiçá, demasiadamente políticas. ${ }^{51} 52$

Partindo dessas constataçóes, é patente que o Judiciário tem um papel estratégico na sociedade. Tal poder não exerce apenas atividades burocráticas e legalistas, mas tem papel importante nas democracias contemporâneas. No sistema common law é comum que o Judiciário adentre na esfera das políticas públicas, pois as normas possuem conteúdo amplo e necessitam de uma complementação ou interpretação. No entanto, nos países que adotam o sistema romano-germânico, como é o caso do Brasil, onde os diplomas são detalhistas e exaustivos, o número de demandas que envolvem políticas públicas está em ascensão, seja devido às lacunas legais, na omissão dos Poderes Legislativo e Executivo, seja no não cumprimento secular dos direitos fundamentais e sociais pelo Estado ou por particulares. ${ }^{53}$

No contexto norte-americano, Owen Fiss entende que a função social do Poder Judiciário está em "dar aplicação e significado concreto aos valores públicos incorporados

50 BARROSO, Luís Roberto. Contramajoritário, representativo e iluminista: papeis das supremas cortes nas democracias contemporâneas. In: Rev. Direito Práx., Rio de Janeiro, Ahead of print, Vol. XX, N. XX, 2017, p. 14.

51 BARROSO, Luís Roberto. Contramajoritário, representativo e iluminista: papeis das supremas cortes nas democracias contemporâneas. In: Rev. Direito Práx., Rio de Janeiro, Ahead of print, Vol. XX, N. XX, 2017, p. 18-19.

52 Nesse sentido, veja o recente artigo do autor sobre as novas tecnologias e Direito: BARROSO, Luís Roberto. Revolução tecnológica, crise da democracia e mudança climática: Limites do Direito num mundo em transformação. Revista de Estudos Institucionais, v. 5, n. 3, p. 1234-1313, dez. 2019. Disponível em: https:// estudosinstitucionais.com/REI/article/view/429/444. Acesso em: 07 jul. 2020.

53 SILVA, Jeovan Assis da; FLORÊNCIO, Pedro de Abreu e Lima. Políticas judiciárias no Brasil: O judiciário como autor de políticas públicas. Revista do Serviço Público Brasília. n. 62. v. 2, p. 119-136 Abr/Jun 2011. p. 119. 
à Constituição" ${ }^{54}$ Todas as instituiçóes públicas e privadas fazem parte do processo de dar vida, sentido e fim para os valores presentes na Constituição. Para o autor, o Poder Judiciário é tão legítimo quanto os Poderes Legislativo e Executivo fornecer essa voz ao Texto Constitucional. Há, dessa maneira, uma contribuiçáo preciosa para o debate público e fomento dos valores públicos. Trata-se de um contexto que ganhou mais vigor na Década de 90, diante das omissóes, abusos e desvios presentes no Legislativo e Judiciário, que falhavam na concretizaçáo dos direitos previstos na Carta Maior. Nessa visão, denominada pelo autor de "reforma estrutural", não há motivo para limitar a participação do Judiciário na formulação de políticas públicas. Inclusive, Fiss também descontrói críticas realizadas pela literatura jurídica, de que o papel do Juiz é apenas e adjudicador, ou seja, a "boca da lei". Diante do crescimento institucional e burocrático do Estado, o Poder Judiciário ganhou um papel chave e "estrutural" de colaborar com a concretização daqueles valores previstos na Constituição. Não significa, entretanto, uma fuga democrática, já que Fiss vê o sistema democrático para além da mera agregação de preferências, baseada na maioria simples. ${ }^{55}$

Há uma aproximação e interconexão das ideias de Fiss no cenário brasileiro, uma vez que o Judiciário também se tornou um fórum de discussôes políticas e de legitimaçáo de grupos sociais e políticos. Inclusive, o posicionamento de Barroso é contemporâneo à construção de Owen Fiss.

Tal leitura não afasta a ideia de que a última esperança de "entrega da justiça" e dos próprios direitos fundamentais foi endereçada ao Poder Judiciário. ${ }^{56}$ Pelo contrário, parece confirmar a insuficiência da lógica tradicional da separação de poderes, pois os dois outros Poderes foram perdendo a sua legitimação em decorrência de interesses privados, do próprio "estamento burocrático", como afirmava Faoro, e da divergência entre grandes grupos políticos. ${ }^{57} \mathrm{~A}$ ausência de uma homogeneidade na concretização dos valores públicos, principalmente na ineficiência da administração pública (que advém da sua origem), em cumprir espontaneamente as prestaçóes e políticas sociais, levou o cidadáo às portas do Judiciário.

Entretanto, as carências do povo não foram e, ainda, não são resolvidas na sua inteireza, tendo em vista que a "soluçáo judicial", ou seja, o Judiciário como instância "salvadora da pátria", passou rapidamente a ser um "problema judicial". ${ }^{58}$ Inclusive,

54 FISS, Owen. Direito como razão pública: processo, jurisdição e sociedade. 2. Ed. Tradução de Carlos Alberto Salles. Curitiba: Juruá, 2017. p. 89.

55 FISS, Owen. The Forms of Justice. Harvard Law Review. v. 93, n. 1, nov. 1979. Disponível em: https:// digitalcommons.law.yale.edu/fss_papers/1220/. Acesso em: 07 jul. 2020. p. 1-17.

56 SILVA, Jeovan Assis da; FLORÊNCIO, Pedro de Abreu e Lima. Políticas judiciárias no Brasil: O judiciário como autor de políticas públicas. Revista do Serviço Público Brasília. n. 62. v. 2, p. 119-136 Abr/Jun 2011. p. 127.

57 FAORO, Raymundo. Os donos do poder: formação do patronato político brasileiro. 3. ed. Rio de Janeiro: Globo, 2001.

58 SILVA, Jeovan Assis da; FLORÊNCIO, Pedro de Abreu e Lima. Políticas judiciárias no Brasil: O judiciário 
alguns economistas apontam para a "Tragédia do Judiciário", 59 em alusão à concepção econômica da Tragédia dos (bens) Comuns de Garrett Hardin. ${ }^{60}$ Tal teoria se refere à problemática da maximização individual de bem-estar em um cenário coletivo, em que todos anseiam pelo mesmo objetivo em um cenário limitado e finito de bens comuns. Hardin afirmava que "a liberdade nos bens comuns arruína a todos. [tradução nossa]." ${ }^{\prime \prime 1}$ Quanto mais se tem disponibilidade de bens comuns, como, por exemplo, o acesso facilitado ao Judiciário, menos se valoriza o bem, ao ponto de se esvaziar o seu valor. Essa visão também está preocupada com o congestionamento gerado pela baixa excludabilidade e alta rivalidade desses bens. ${ }^{62}$ Entretanto, a limitação aos bens comuns é um tema delicado e que depende de consenso social sobre qual saída adotar.

Assim, o juiz sobrecarregado com as atribuiçōes dos outros Poderes, se viu em um mar de petiçōes que além de ser extenso é também de águas turbulentas. Impossível de nadar ou navegar, pois não foi preparado tecnicamente para absorver problemas de formulação e implementação de políticas públicas e, consequentemente, de orçamento. Isso gera morosidade judicial e custos econômicos, políticos e sociais na demora no julgamento das demandas. Reformas institucionais no Poder Judiciário brasileiro ocorreram justamente para tentar corrigir essas falhas. A criação do Conselho Nacional de Justiça foi uma delas. ${ }^{63}$

$\mathrm{O} \mathrm{CNJ}$ surgiu justamente para tentar contornar os problemas sistêmicos do Judiciário. Problemas estes decorrentes da sua grande dimensão em número de tribunais, órgãos e divisões (justiça estadual, federal e especializadas), que não possuíam coordenação administrativa, bem como de resquícios patrimonialistas de períodos remotos, tal como a corrupção. Nesse passo, "o CNJ tem se firmado como um importante ator do sistema judicial, na medida em que a definição e a implementação de políticas judiciárias, (...) constituem um dos aspectos essenciais de sua atuação." ${ }^{64}$ Apesar das tentativas de melhora

como autor de políticas públicas. Revista do Serviço Público Brasília. n. 62. v. 2, p. 119-136 Abr/Jun 2011. p. 130.

59 GICO JR., Ivo Teixeira. A tragédia do judiciário: subinvestimento em capital jurídico e sobreutilização do judiciário. 2012. 163 f. Tese (Doutorado em Direito). Universidade de Brasília, Brasília, 2012.

60 HARDIN, Garrett. The Tragedy of the Commons. Science, New Series, v. 162, n. 3859, Califórnia, 1968, p. $1243-1248$.

61 HARDIN, Garrett. The Tragedy of the Commons. Science, New Series, v. 162, n. 3859, California, 1968, p. 1244.

62 Sobre a Teoria Econômica dos bens, veja: GICO Jr., Ivo Teixeira Gico. A natureza econômica do direito e dos tribunais. Revista Brasileira de Políticas Públicas - RBPP, Brasília, v. 9, n. 3, p. 12-39, 2019.

63 É interessante notar que os "Conselhos de justiça remontam ao contexto histórico da Europa pós II Guerra Mundial, tendo a ideia se difundido especialmente em países sem Judiciários autônomos e independentes em matéria administrativa, nos quais a gestão judicial costumava ficar a cargo do Executivo, em órgãos com atribuiçóes similares àquelas exercidas pelo Ministério da Justiça no Brasil. Atualmente, os conselhos judiciais estão amplamente difundidos ao redor do mundo, ainda que assumam diferenciados formatos institucionais de acordo com os ajustes necessários para cada sistema judicial nacional.” SILVA, Jeovan Assis da; FLORÊNCIO, Pedro de Abreu e Lima. Políticas judiciárias no Brasil: O judiciário como autor de políticas públicas. Revista do Serviço Público Brasilia. n. 62. v. 2, p. 119-136 Abr/Jun 2011. p. 122.

64 SILVA, Jeovan Assis da; FLORÊNCIO, Pedro de Abreu e Lima. Políticas judiciárias no Brasil: O judiciário como autor de políticas públicas. Revista do Serviço Público Brasília. n. 62. v. 2, 119-136 Abr/Jun 2011. p. 123. 
no sistema Judiciário, há problemas que decorrem da legitimação desse Poder no exercício das suas funçóes. $\mathrm{O}$ exemplo dos ataques virtuais e de grupos articulados ao Supremo Tribunal Federal, ocorridos entre 2018 e 2020, podem servir de exemplo de diminuição dessa legitimidade. ${ }^{65}$

Apesar disso, é possível afirmar que o Poder Judiciário pode formular e implementar políticas públicas. Inclusive, como delineado acima, há uma importância estratégica do Judiciário nas democracias contemporâneas. Nesse passo, as políticas públicas não são construções exclusivas de um Poder específico, mas são ações do Estado (e em alguns casos de agentes privados) voltadas a concretização de conteúdos normativos constitucionais. Assim, as políticas públicas estariam ligadas a ideia de governança, "conceito amplo que envolve a proteção dos direitos dos cidadãos, a base legal apropriada à busca do progresso econômico e social, as condições indispensáveis à atuação do setor empresarial, a alocação eficiente e eficaz de recursos públicos." 66

Essas consideraçóes realizadas sobre a possibilidade de o Poder Judiciário interferir na formulação e execução de políticas públicas pode ser explicada também na vertente do Direito Constitucional, principalmente no que tange a ascensão específica dos tribunais constitucionais. Luís Roberto Barroso afirma que os tribunais constitucionais atuais possuem três papéis essenciais, quais sejam: contramajoritário, representativo e iluminista. ${ }^{67} \mathrm{O}$ autor ressalta que atualmente o direito constitucional contemporâneo é marcado pela ascensão política e institucional do Poder Judiciário. As principais marcas dessa evolução está na judicialização, no ativismo judicial, no esforço da justificação democrática da jurisdição constitucional. Para o autor, o Judiciário estaria no caminho correto. $^{68}$

65 Sessão solene do STF em 03/04/2019, sobre os discursos virtuais de ódio voltados ao STF. PONTES, Felipe. É preciso ser firme na defesa do Supremo, diz Toffoli em ato solene. In: AGÊNCIA EBC, Brasília, 3 maio 2019. Disponível em: http://agenciabrasil.ebc.com.br/justica/noticia/2019-04/e-preciso-ser-firme-na-defesado-supremo-diz-toffoli-em-ato-solene. Acesso em: 16 jan. 2020.

66 SILVA, Jeovan Assis da; FLORÊNCIO, Pedro de Abreu e Lima. Políticas judiciárias no Brasil: O judiciário como autor de políticas públicas. Revista do Serviço Público Brasília. n. 62. v. 2, 119-136 Abr/Jun 2011. p. 125.

67 Barroso afirma que o Poder Legislativo prefere que o Judiciário resolva temas polêmicas como aborto, união homoafetiva, legalização de drogas consideradas ilícitas, remédios de alto custo, pois tais questóes são demasiadamente polarizadas. BARROSO, Luís Roberto. Contramajoritário, representativo e iluminista: papeis das supremas cortes nas democracias contemporâneas. In: Revista Direito Práx., Rio de Janeiro, v. 9, n. 4, 2018. p. 2182.

68 Cabe mencionar que Barroso faz uma distinção entre a judicialização, acima descrita, do ativismo judicial. Nesse passo, o ativismo judicial se refere a expressão americana cunhada para designar o período em que Earl Warren presidiu a Suprema Corte nos Estado unidos, pois adotou em inúmeros casos uma corrente progressista em matéria de direitos fundamentais. Assim, a reação a tal corrente foi a utilização do termo com uma conotação negativa. Assim, o sentido específico do termo estaria “(...) associada a uma participação mais ampla e intensa do judiciário na concretizaçáo dos valores e fins constitucionais, com maior interferência no espaço de atuação dos outros dois poderes." Dessa forma, enquanto a judicialização é uma constatação, o ativismo é uma atitude que revela a escolha de uma forma proativa de decidir e interpretar a Constituição. BARROSO, Luís Roberto. Contramajoritário, representativo e iluminista: papeis das supremas cortes nas democracias contemporâneas. In: Revista Direito Práx., Rio de Janeiro, v. 9, n. 4, 2018. p. 2183. 
Pelo primeiro papel, o Judiciário teria a "função contramajoritária" de invalidar os atos dos Poderes Executivo e Legislativo. Cabe mencionar que a legitimidade para essa atividade advém de dois fundamentos: a proteção dos direitos fundamentais; e, a proteção das regras do jogo democrático e da participação política de todos. Assim, a jurisdição constitucional exerceria uma atividade de sentinela contra abusos e ilegalidades. ${ }^{69}$

Por sua vez, o "papel representativo" funciona para que o judiciário atenda as demandas que foram relegadas pelos outros dois poderes. Como mencionado acima, a crise do Legislativo ressaltou a importância do Poder Judiciário. Além disso, a qualificação técnica dos membros, as garantias como a vitaliciedade e os deveres como o de motivar as decisóes, enalteceu a essencialidade desse Poder. O fundamento democrático de tais decisóes reside na democracia contemporânea que pode ser dividida em representativa (voto popular), constitucional (respeito aos direitos fundamentais) e deliberativa (oferecimento de razóes, discussão de argumentos e troca de ideias). Assim, sabendo que a representaçáo popular é apenas uma das vertentes da democracia contemporânea, o judiciário encontra força na vertente deliberativa dessa democracia. Nesse passo, são exemplos de decisões representativas no Supremo Tribunal Federal: nepotismo, prisão em segunda instância e financiamento de campanhas eleitorais. ${ }^{70}$

O Poder Judiciário exerce, também, um “papel iluminista”. Nessa vertente o Judiciário promove avanços, mesmo que maiorias políticas eventuais tentem barrar o progresso. Tal papel é excepcional e deve ser usado com parcimônia. Os avanços devem ser em nome da razão. Essa importante função é destinada ao Judiciário porque algumas mudanças complexas não são concretizadas pelos mecanismos tradicionais de solução de reinvindicaçóes sociais. Pode-se citar como exemplos de "decisóes iluministas" no Supremo Tribunal Federal: vaquejada, união homoafetiva e aborto até o terceiro mês de gestação. $^{71}$

Após perquirir o cenário delineado acima e resgatar a interconexão proposta neste artigo entre herança histórica e expansão do Poder Judiciário, é possível concluir que não há uma clara conexão entre as temáticas. A expansão não é um fenômeno exclusivamente brasileiro. É, na verdade, um fenômeno estrangeiro e, quiçá, global. Trata-se de uma tentativa de harmonizar e concretizar os anseios dos cidadãos, que não ganharam o tratamento adequado pelos Poderes Legislativo e/ou Executivo. Entretanto, as perspectivas históricas reforçaram a problemática das demandas seculares não concretizadas, o que gera uma corrida ao Poder Judiciário. Assim, a tentativa desse Poder de abraçar toda essa

69 BARROSO, Luís Roberto. Contramajoritário, representativo e iluminista: papeis das supremas cortes nas democracias contemporâneas. In: Revista Direito Práx., Rio de Janeiro, v. 9, n. 4, 2018. p. 2197.

70 BARROSO, Luís Roberto. Contramajoritário, representativo e iluminista: papeis das supremas cortes nas democracias contemporâneas. In: Revista Direito Práx., Rio de Janeiro, Ahead of print, V. 9, N. 4, 2018. p. 2200.

71 BARROSO, Luís Roberto. Contramajoritário, representativo e iluminista: papeis das supremas cortes nas democracias contemporâneas. Revista Direito Práx., Rio de Janeiro, v. 9, n. 4, 2018. p. 2207. 
carga deficitária de políticas públicas, não revela necessariamente uma extrapolação de suas competências, mas pode indicar um grave problema: o congestionamento judicial. Temática que possui correlação direta com essa herança histórica brasileira e merece ser aprofundada em textos futuros.

\section{Conclusão}

Os aspectos históricos descritos nesse artigo científico, que não se propôs a esgotar a temática histórica e literária, enfatizou em grande parte o elemento humano do Estado brasileiro. Isso decorre da importância da formação do povo brasileiro na estruturação das instituiçóes públicas. A pluralidade de interpretaçóes dos Clássicos revela dados importantes para o entendimento da realidade brasileira. A convivência de um patrimonialismo e de um estamento burocrático no ambiente institucional, marcou a interferência do "privado" no "público" e do não atendimento de demandas sociais importantes. Assim, apesar das "reformas formais" realizadas pelo Estado, ainda existem falhas na concretização dos direitos fundamentais e sociais.

Esse cenário é agravado com a morosidade ou omissão dos Poderes Legislativo e Executivo, diante das demandas sociais. Restando ao cidadão recorrer ao Judiciário para pleitear direitos que historicamente permanecem na pendência de serem concretizados. Tal realidade favoreceu a utilização do Poder Judiciário como uma espécie de "última instância”, para que as políticas públicas ausentes ou deficitárias fossem criadas ou corrigidas. Apesar de a literatura especializada apontar avanços democráticos advindos dessa interferência, existe uma vertente doutrinária que aponta os problemas dessa transferência de tarefas institucionais. $\mathrm{O}$ juiz não tem domínio do cenário de cada ente federativo no tocante ao orçamento e às políticas públicas já concretizadas. $\mathrm{O}$ deslocamento indevido de recursos movimentados pelas demandas judiciais pode acabar prejudicando a sua alocaçấo eficiente.

Entretanto, a hipótese indicada neste artigo foi infirmada, pois não se identificou uma clara conexão entre a história colonial e a expansão institucional do Poder Judiciário. O enaltecimento desse Poder ocorreu, antes de tudo, no cenário estrangeiro, com movimentos que forneceram uma nova visão estrutural à atividade judicial e promoveram a ascensão das cortes constitucionais. A história brasileira tem um importante papel nessa temática, mas não é o fenômeno principal que explica o avanço do Judiciário na formulação de políticas públicas. Tal constatação, não afasta a importância da leitura dos clássicos brasileiros para que se compreenda as deficiências atuais na concretização dos direitos. Trata-se, acima de tudo, de uma espécie de condicionante para a compreensão da nossa história e para a coordenaçáo do nosso futuro. 


\section{Referências}

APPIO, Eduardo. O Controle Judicial de Politicas Públicas no Brasil. Curitiba: Juruá, 2009.

BARROSO, Luís Roberto. Contramajoritário, representativo e iluminista: papeis das supremas cortes nas democracias contemporâneas. Revista Direito Práx., Rio de Janeiro, v. 9, n. 4, 2017.

BARROSO, Luís Roberto. Revolução tecnológica, crise da democracia e mudança climática: Limites do Direito num mundo em transformação. Revista de Estudos Institucionais, v. 5, n. 3, p. 1234-1313, dez. 2019. Disponível em: https:// estudosinstitucionais.com/REI/article/view/429/444. Acesso em: 07 jul. 2020.

BUCCI, Maria Paula Dallari. Políticas públicas: reflexóes sobre o conceito jurídico.In: BUCCI, Maria Paula Dallari (Org.). O conceito de política pública em direito. São Paulo: Saraiva, 2006.

CARDOSO, Fernando Henrique. Pensadores que inventaram o Brasil. São Paulo: Companhia das Letras, 2012.

FAORO, Raymundo. Os donos do poder: formação do patronato político brasileiro. 4. ed. Rio de Janeiro: Globo, 2008.

FISS, Owen. Direito como razão pública: processo, jurisdição e sociedade. 2. Ed. Tradução de Carlos Alberto Salles. Curitiba: Juruá, 2017.

FISS, Owen. The Forms of Justice. Harvard Law Review. v. 93, n. 1, nov. 1979. Disponível em: https://digitalcommons.law.yale.edu/fss_papers/1220/. Acesso em: 07 jul. 2020.

FREYRE, Gilberto. Casa Grande \& Senzala. 47. ed. Global: São Paulo, 2003.

FURTADO, Celso. Formação econômica do Brasil: Edição Comemorativa 50 Anos. São Paulo: Companhia das Letras, 2009.

GICO Jr., Ivo Teixeira Gico. A natureza econômica do direito e dos tribunais. Revista Brasileira de Políticas Públicas - RBPP, Brasília, v. 9, n. 3, p. 12-39, 2019.

GICO JR., Ivo Teixeira. A tragédia do judiciário: subinvestimento em capital jurídico e sobreutilização do judiciário. 2012. 163 f. Tese (Doutorado em Direito). Universidade de Brasília, Brasília, 2012.

HOLANDA, Sérgio Buarque de. Raizes do Brasil, 26. ed. São Paulo: Companhia da Letras, 2008. 
KEANE, John. A vida e a morte da democracia. Tradução de Clara Colloto. São Paulo: Ediçóes 70, 2010.

LEAL, Victor Nunes. Coronelismo, enxada e voto: o município e o regime representativo no Brasil. 7. ed. São Paulo: Companhia das Letras, 2012.

LEVITSKY, Steven; ZIBLATT, Daniel. Como as democracias morrem. Tradução de Renato Aguiar. Rio de Janeiro: Zahar, 2018.

OLIVEIRA, Francisco de. Jeitinho e jeitão: Uma tentativa de interpretação do caráter brasileiro. Revista Piauí, São Paulo, v. 7, n. 73, p. 32-34, out. 2012.

OLIVEIRA, Luciano Moreira de. O Ministério Público brasileiro e a implementação de políticas públicas. Revista de Informação legislativa, Brasília, v. 50, n. 198, p. 223238, abr./jun. 2013.

ONU. Brasil está entre os cinco paises mais desiguais. 29 jan. 2018. Disponível em: https://nacoesunidas.org/brasil-esta-entre-os-cinco-paises-mais-desiguais-diz-estudo-decentro-da-onu/. Acesso em: 15 jan. 2020.

PRADO JÚNIOR, Caio. Formação do Brasil contemporâneo, 8. ed. São Paulo: Brasiliense, 1965.

PONTES, Felipe. É preciso ser firme na defesa do Supremo, diz Toffoli em ato solene. In: AGÊNCIA EBC, Brasília, 03 maio 2019. Disponível em: http://agenciabrasil.ebc. com.br/justica/noticia/2019-04/e-preciso-ser-firme-na-defesa-do-supremo-diz-toffoliem-ato-solene. Acesso em: 16 jan. 2020.

RICUPERO, Bernardo (org.). Sete liçôes sobre as interpretaçöes do Brasil. São Paulo: Alameda, 2007.

SILVA, Jeovan Assis da; FLORÊNCIO, Pedro de Abreu e Lima. Políticas judiciárias no Brasil: O judiciário como autor de políticas públicas. Revista do Serviço Público, Brasília, v. 2, n. 62, p. 119-136, Abr./Jun. 2011.

SILVA, Virgílio Afonso. O Judiciário e as políticas públicas: entre transformação social e obstáculos à realização dos direitos sociais, Direitos sociais: fundamentos, judicialização e direitos sociais em espécie. Rio de Janeiro: Lúmen Juris, 2010.

SILVEIRA, Daniel Barile da. Patrimonialismo e burocracia: uma análise sobre o poder judiciário na formação do estado brasileiro. 2006. 301 f. Dissertação (Mestrado em Direito). Universidade de Brasília, Brasília, 2006.

SOUZA, Jessé. A ralé brasileira: quem é e como vive. Belo Horizonte: UFMG, 2001.

WEBER, Max. Economia e Sociedade: Fundamentos da sociologia compreensiva. Volume 1. Tradução de Regis Barbosa e Karen Elsabe Barbosa. São Paulo: UnB, 2004. 